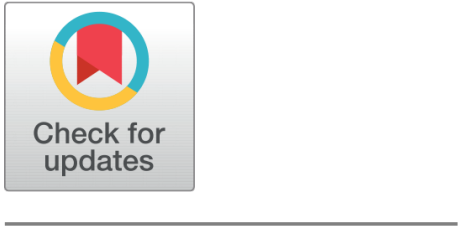

OPEN ACCESS

Received: 29-06-2020

Accepted: 27-07-2020

Published: 11-08-2020

Editor: Dr. Natarajan Gajendran

Citation: Khaskheli GA, Rajper ZA, Mangi QA, Hussain RS, Shar AH

(2020) A mediation analysis of social media marketing between the relationship of entrepreneurial marketing strategies and the performance of small \& medium enterprises in Pakistan. Indian Journal of Science and Technology 13(29): 2924-2934. https://doi.org/ 10.17485/IJST/v13i29.1035

* Corresponding author.

g_akbark@yahoo.com

Funding: None

Competing Interests: None

Copyright: (c) 2020 Khaskheli et al. This is an open access article distributed under the terms of the Creative Commons Attribution License, which permits unrestricted use, distribution, and reproduction in any medium, provided the original author and source are credited.

Published By Indian Society for Education and Environment (iSee)

ISSN

Print: 0974-6846

Electronic: 0974-5645

\section{A mediation analysis of social media marketing between the relationship of entrepreneurial marketing strategies and the performance of small \& medium enterprises in Pakistan}

\author{
Ghulam Akbar Khaskheli ${ }^{1 *}$, Zulfiqar Ali Rajper ${ }^{2}$, Qamar Abbas Mangi ${ }^{1}$, \\ Raja Sajid Hussain ${ }^{1}$, Akhtiar Hussain Shar ${ }^{1}$ \\ 1 Institute of Commerce, Shah Abdul Latif University, Khairpur \\ 2 Department of commerce, Shaikh Ayaz University, Shaikarpur
}

\section{Abstract}

Objectives: The main focus of this study is to find the role of social media marketing between the relationship of entrepreneurial marketing strategies and Performance of Small and medium enterprises (SMEs) in Pakistan. This research will answer the question that how social media marketing can be crucial for the entrepreneurial marketing to increase the performance of small and medium enterprises in Pakistan. Methodology: The SMEs operating in Pakistan have been considered and the respondents are the Marketing Managers of SMEs. The total number of SME's in Pakistan is 3.3 million having one marketing manager. The total population of study is 3.3 million. Roscoe 1975 technique has used for selecting sample size. The 384 SME's managers were selected through Roscoe sampling method and survey instrument has randomly been distributed among the marketing managers of SMEs in Pakistan through the primary data collection mode. Discussion: Hypotheses have been tested through "Structural Equation Modeling". Since SEM is latest second generation tool of multivariate analysis and it has been used in this study to test the hypothesis. Findings: It is found from the results and discussion that entrepreneurial marketing strategies; proactive orientation, value creation, innovativeness and customer focus plays important role in enhancing the SMEs performance in Pakistan and Social media marketing can highly be effective to implement entrepreneurial marketing strategies to improve the performance of small and medium enterprises in Pakistan.

Keywords: Entrepreneurial marketing strategies; SMEs Performance; role of social media marketing

\section{Introduction}

This paper extends previous research, revisit and seeks to address the realm of innovative marketing and entrepreneurial marketing ${ }^{(1)}$. Focus is to explain the innovative and 
entrepreneurial marketing, conceptual framework, practice theory and integrating academic, which always referred as theory for sake of practice ${ }^{(2)}$. As innovation and entrepreneurship has no one defining theory, there are unresolved and constant tension, between practice and theory. Practical theory comes from intuitive, implicit, practice situated resources and tacit ${ }^{(3)}$. To surpass problems, entrepreneurial organizations require having a proactive approach towards marketing which reflects by the following uniqueness of entrepreneurial marketing: Entrepreneurial industry is persistently finding for latest traditions to achieve competitive advantage through change in usual methods, in production or marketing ${ }^{(4)}$. Firms that are Innovative have ability to manage the stream of new ideas which could be translated into new services or products ${ }^{(5)}$. To develop, retain and to acquire customers an entrepreneurial firm have to focus on creative approaches. The entrepreneurial firm may equip with customer's requirement to make a knowledge base by paying attention on customer's needs ${ }^{(6)}$. Entrepreneurial marketing's important facet is innovative value creation because value creation is important measure for relationships and transactions ${ }^{(7)}$. General Objectives: Generally, the study try to identify the new ways the entrepreneurs can use to enhance the performance of SME's largely through adopting the six most effective Marketing strategies with the help of an understanding the organizational culture and the social media marketing which in modern world, is a most renounced technique to achieve marketing goals ${ }^{(8)}$. The first thing, this study makes a remarkable addition in the existing literature on the entrepreneurial marketing, social media marketing, organizational culture and performance, in means of financial and strategic performance of small, medium enterprises ${ }^{(9)}$. This study significantly will define the relationship among these selected study variables which in future will provide a great insight to the government and other organizations to make SME's to perform better from the existing conditions ${ }^{(10)}$.

\subsection{Importance of SMEs in Pakistan}

The SMEs constitutes 90\% of business in Pakistan. They symbolize a considerable part of Pakistan's economy in terms of both and employment generation and value addition. They primarily offer employment to groups with low income. They are also measured as an important scheme for poverty reduction. The SMEs in particular, play a vital role in manufacturing sector, providing $80 \%$ of the industrial labor force and contributing around 40\% to GDP and generating one fourth of the sector's export earnings ${ }^{(11)}$.

The paper consisted on given headings in the section 1 introduction has been discussed, of the entrepreneurial marketing strategies with major focus on the performance of small and medium enterprises and section 2 has shown the previous related work. Section 4 has shown the methodology of the paper and section 4 has discussed the paper results. In the last section 5 , has discussed the conclusion of the paper.

\subsection{Objectives}

- To explore that either Social media marketing mediates the relationship between the entrepreneurial marketing strategies and performance of SMEs in the Pakistan or not?

- To explore the impact of social media marketing on the performance of SMEs in Pakistan

- To explore the relationship between the entrepreneurial marketing strategies and social media marketing.

- To explore the impact of entrepreneurial marketing strategies on the performance of SMEs in Pakistan

\section{Previous studies}

\subsection{Entrepreneurial marketing Strategies}

Though enough studies highlighted and written on innovative marketing and entrepreneurship literature, thus; this study intended to provide essence regarding the definition, history and to know the peculiarities only to this method of marketing ${ }^{(12)}$. We take awareness regarding prevailing marketing orientation concepts as an essential contributor to new venture and business performance ${ }^{(12)}$. Furthermore, this study has explained the importance of interaction of innovative marketing and entrepreneurship ${ }^{(13)}$. Entrepreneurship Operates in a traditional marketing environment since the early 1990's, Downtown Intellectuals has been working on areas of interface between the Internet and marketing, which have now evolved within main market research ${ }^{(14)}$. Even more progress has been made in identifying and conceptualizing specific business and innovative market ideas. Conceptualizes the risk that security identification and exploitation of opportunities for acquiring and retaining profitable customers through innovative methods of risk management, resource consolidation and value creation and facilitates opportunity management of opportunity management ${ }^{(15)}$. This tool of thinking enhances the relationship between editorial and marketing, and serves as an executor for thousands of startups and innovators in many landscape manufacturers gives insights with marketing contradictions. For this purpose, ${ }^{(16)}$ emphasizing unity through the dimension of security agency, mobility of 
the movement, customer intensity, focus on innovation and request are related, such as opportunity assessment ${ }^{(17)}$. Despite this, ${ }^{(18)}$ facilitated the promotion of entrepreneurs, applying the entrepreneurial dimension to marketing culture, strategy and tactics. While ${ }^{(19)}$ do not provide a direct description of entrepreneurial marketing, they emphasize the interface of change focus, opportunity in nature and innovation in style. The authors are further underscored by giving marketers a business that includes entrepreneurial culture, business management and business thought.

\subsection{Social media marketing and entrepreneurship}

When customary marketing practices are inappropriate for small and medium enterprises, entrepreneurs have to refine conventional philosophy and change them according to latest modern beliefs and procedures, such as entrepreneurial marketing (EM). Results reveal that participants are likely to be opportunity oriented and recognize the significance of resource leveraging. Although value creation is seen as an incredibly important entrepreneurial marketing element, participants are kept with respect to intriguing risks; in addition, they need not be inclined to be innovative, proactive, nor customer slanting ${ }^{(20)}$. The outcomes reveal that, the total impact of factors that control the behavioral intention to use social media channels of customers is ranked as under,perceived enjoyment, accessibility, perceived usefulness, reliance of social media channels, perceived ease of use, attitude, social influence and self-efficacy ${ }^{(21)}$. The entrepreneurship internationalization is becoming progressively more facilitated by the use of internet. The expression "internalization" to pass on to the method of escalating implementation, flow, and use of internet-based processes and technologies that progressively serves as spine of internationalization, particularly in the innovative entrepreneurial companies. This method possibly compared to firm's implementation and employing of internet and internet-based methods in transforming firm to an amalgam network externally and internally inside the international markets and firm's home, particularly when the members of its external network have already internationalized ${ }^{(22)}$.

Our focus is on communication and information technology sector to check links between outcomes and founder profiles. Using logistic regressions, we tried to find differences among a pre-recognized five-group typology of entrepreneurs. We found that profiles were changed strongly in sense of survival and observed varying human capital impact on business survival. Results suggest negative impact of opportunity costs, not significant and negative results of company and management experience, and also no impact of entrepreneurship preparation and capital. We found that a critical business firm size is necessary to enable entrepreneurial learning in organizations. On the contrary, we have confirmed that usual observed impact does not hold in particular contexts. We also have observed a positive mediating effects of variables, replacing a lack of attributed assets to successful new firm performance. Our findings are crucial to opt for entrepreneurship policy and to identify winners and risk $\operatorname{takers}^{(23)}$.

Social media have a partially significant effect on consumers' buying behavior in Pakistan; content credibility and word of mouth(WOM) are two factors that emphasise consumers' buying behavior in Pakistan. Cconsumers in Pakistan, under the age of 35, have more unpredictable buying behavior, that make entrepreneurs very conscious to consider it for marketing strategies for future. Entrepreneurs have to make a strategy to be very different from others keeping customers aware of the service or products they offer. On the other hand, customers must not spend huge time while selecting brands, rather, companies must make it so captive ${ }^{(24)}$. If we admit that entrepreneurs can be influenced by social culture, then the simplest doable unit of research for accepting entrepreneurship is not the entrepreneur. It is uncertain, in that case, that a mail study or still interviews can be adequate for a researcher to accurately gain a holistic understanding of entrepreneurial process ${ }^{(25)}$. Socioeconomic, structural and religious forces play an important role in suppressing or limiting cultural capital, social capital and stifling entrepreneurial courage in rural areas of Pakistan, clearing up the low intensity of entrepreneurship in these areas. Cultural and Social capital requires a precise socioeconomic background for entrepreneurship to flourish ${ }^{(26)}$.

\subsection{Entrepreneurial marketing strategies and SMEs performance}

The latter is related to industry and job experience, productivity and marketability, namely communication skills and voice judgment ${ }^{(27)}$. These capabilities, however, are not inventive for alien entities. ${ }^{(28)}$ Integrating the entrepreneurial marketing process into a new dimension of competitive advantage. They are not directly related to investment, but find out how big companies use the entrepreneurial marketing process to leverage or renew competition by integrating close marketing investment with EM strategies. ${ }^{(29)}$ EM/entrepreneurial marketing strategies examined in small and medium enterprises which are reflective of institutional directions in the system. One must note that not all SMEs reflect an institutional core role ${ }^{(30)}$. Nevertheless, it highlights the context of the EM, highlighting the suitability of the research interface: sales and sales more pragmatic approach to EMS reveals that successful companies invest in unconventional market practices. They focused on innovation first, and only on customer needs. The following is a way for clients to evaluate, adjust, target, and adopt positional strategies. In addition, they rely on advertising marketing techniques, rather than the mix of more traditional markets. 
In agreement here, emphasize unconventional plans, but neglecting customer needs, or rather, lack of customer centricity is inconsistent with many scholars ${ }^{(30,31)}$. Nevertheless, Stoics enlarges the body of knowledge with conscious individuals, practicing theory ${ }^{(26)}$. To date, ${ }^{(32)}$, approve recipes for promotion of advertising management. Such relationships include innovation, new project planning, development and uniqueness. Interestingly, this is the reason why non-profits are associated with the marketing interface. The International Marketplace Locator is a marketing strategy for small companies that help them to rise by entrepreneurship ${ }^{(33)}$. EM combines the critical concept of entrepreneurship and marketing with a comprehensive concept where marketing executes the process that firms use to work as an institution. Hence, ${ }^{(34)}$ explains that the nonlinear, invariant, and vision marketing practices of the enterprise are also known as I.M. Business marketing is considered as a marketing strategy to explore the benefits and opportunities of advertising in business entrepreneurship, using the opportunity to define business innovation and the potential for innovation ${ }^{(35)}$. In addition, ${ }^{(36)}$ states that, the process of acquiring and leveraging MEP customers, through exploration of opportunity, new approaches to risk management, resource management and value. To create in addition, ${ }^{(37)}$ claimed that EM provides four dimensions of entrepreneurship. Therefore, the payment marketing is a combination of institutional introduction and orientation. In $^{(38)}$ also explained the idea of EM using the framework for inventive business, which consists of two principles: first principle is entrepreneurship which defines method of opportunity orientation. Another principle is assets that create value for customers. It builds with group effort between different actors that increases customer value. The third principle is the process in which the value concept gets positioned. The final principle is the actors, organizations or individuals that create the custom values and practices ${ }^{(39)}$. Performance is a construct that has different meanings in the academic literature. In general, social media advertising enhances performance, investment performance, strategy effectiveness, customer satisfaction, market growth, returns and integrates the arts and knowledge into a complex series of integrative processes. ${ }^{(40)}$ Mentions that the evaluation of performance of the SMEs is very important to monitor the success of the firm in order to take appropriate steps to cope with it ${ }^{(41)}$. Concerning that, ${ }^{(42)}$ stated that the statement of the SMEs performance, would show how well a firm makes it. In addition, ${ }^{(43)}$ explains that SMEs performances are considered to be the result of constructive management activities and should be evaluated for exploitation of several criteria, including efficiency, effectiveness, productivity and growth. In fact, the performance of an SME is the ability of a firm to meet the wishes of its stakeholders ${ }^{(44)}$. Hence performance has the potential to ensure satisfactory results and actions to be achieved ${ }^{(44)}$ and thus to identify its position in terms of a strong and weak point through the evaluation of a proven MME performance. In addition, the purpose of the evaluation of SME performance is to improve the range of opportunities ${ }^{(45)}$, whether internal or external, to achieve the overall potential best and to achieve desirable development over time ${ }^{(45)}$.

\subsection{Conceptual model}

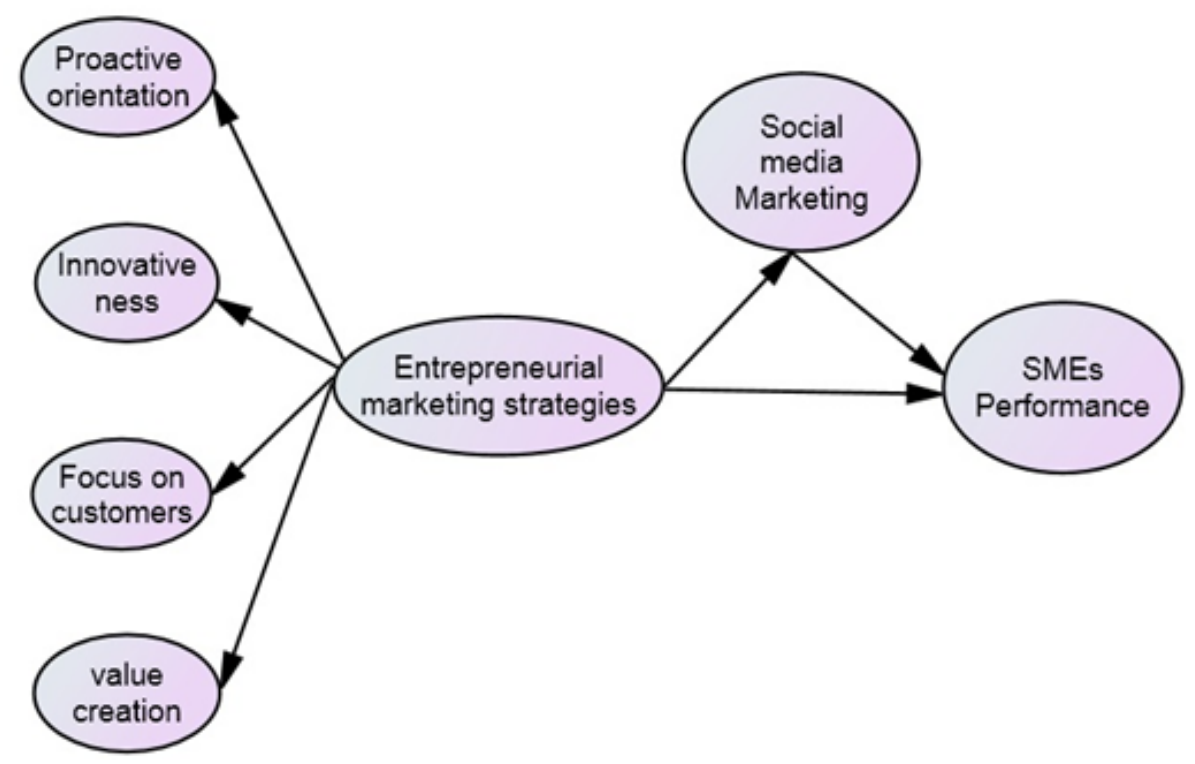

Fig 1. Shows the conceptual model 
The research model shown below in the Figure 1 has one exogenous variable that is entrepreneurial marketing strategies with four dimensions; proactive orientations, innovativeness, focus on customer and value creation. This Construct will be measured by using these four dimensions. On the other side small and medium enterprises' performance is Figure 1 shows as exogenous variables in model with a mediator Social media marketing.

\subsection{Hypothesis}

H1. The proactive orientation, innovativeness, focus on customer, value creation are the measures of entrepreneurial marketing strategy and has a significant impact on the performance of SMEs in the Pakistan.

H2. The social media marketing has significant and positive relationship with marketing entrepreneurial strategies.

H3. The social media marketing significantly influencing the performance of SMEs in Pakistan

H4. Social media marketing significantly mediates the relationship between the entrepreneurial marketing strategies and performance of SMEs in the Pakistan.

\section{Methodology}

The small and medium enterprises working in Pakistan have been targeted. The targeted sample population is the marketing managers of small and medium enterprises in Pakistan. The total number of SME's in Pakistan is 3.3 million.

According to the share in economy SMEs in Pakistan are represented in percentage form: Table 1 shows the Types of SMEs selected for study;

Table 1. Type of SMEs working in Pakistan in \%

\begin{tabular}{lll}
\hline S.No. & Type of SME & Total number of SMEs in $\%$ \\
\hline 1. & Wood \& furniture & $10 \%$ \\
2. & Grain milling & $4 \%$ \\
3. & Jewelry & $16 \%$ \\
4. & Carpets & $5 \%$ \\
5. & Art silk & $4 \%$ \\
6. & Cotton weaving & $7 \%$ \\
7. & Metal products & $13 \%$ \\
8. & Textiles & $6 \%$ \\
9. & Others & $35 \%$ \\
\hline
\end{tabular}

Table 2 shows the number of marketing managers selected according to the proportionate method:

Table 2. Selected Sample Size

\begin{tabular}{|c|c|c|c|}
\hline S.No. & Type of SME & Total number of SMEs in \% & Selected Sample Size \\
\hline 1. & Wood \& furniture & $10 \%$ & 38 \\
\hline 2. & Grain milling & $4 \%$ & 15 \\
\hline 3. & Jewelry & $16 \%$ & 62 \\
\hline 4. & Carpets & $5 \%$ & 19 \\
\hline 5. & Art silk & $4 \%$ & 15 \\
\hline 6. & Cotton weaving & $7 \%$ & 27 \\
\hline 7. & Metal products & $13 \%$ & 50 \\
\hline 8. & Textiles & $6 \%$ & 24 \\
\hline \multirow[t]{2}{*}{9.} & Others & $35 \%$ & 134 \\
\hline & Total & $100 \%$ & 384 \\
\hline
\end{tabular}

According to nature, positivism research philosophy has used due to the large population size of study and in this study the 384 SMEs were selected through proportionate sampling and random sampling technique of probability sampling method has been used to distribute the questionnaire among the SMEs marketing mangers ${ }^{(46)}$, Provides the 'rule of thumb' for sample size and declares that sample size, between 50 and 500 is appropriate. Whereas, experts suggest that data ranges between 5 - 10 times 
the number of items used in the scale ${ }^{(46)}$. According to study nature a quantitative method is applied and for that, structured survey was conducted through the primary data collection mode. Hypotheses have been tested through "Structural Equation Modeling". Since SEM is latest second, generation tool of multivariate analysis. SEM has been used in this study.

\section{Results \& Discussion}

For the variable, entrepreneurial marketing strategies, this study has adopted and modified items from scale given by ${ }^{(46)}$. From the work of ${ }^{(46)}$, this study has adopted and customized items. Moreover, the direct and mediating effect of social media marketing was determined through modified and customized items of social media marketing and instrument was given by ${ }^{(46)}$. This study has used 5-point scale for all three constructs. Later some of items were eliminated in the modification indices which are explained in detailed in the description of Figure 1. CFA

In Figure 2 , the variables are six in number. The variable EMS is exogenous variables where as SMM is intervening variable and small and medium enterprises performance is endogenous variable. According to CFA of model results, the Chi-Square is 493.588 where as P-Value is also .000 which shows the significance of model. The GFI value must be below $1^{(47)}$ but not less than .85. The value of this model is .892 where AGFI is .856, TLI, .950, CFI, .959, PCFI, .794, RMSEA, .069 and the P-Close is also .000 . All value is in sphere of values which proves a model fit. According to mentioned value the model is fit.

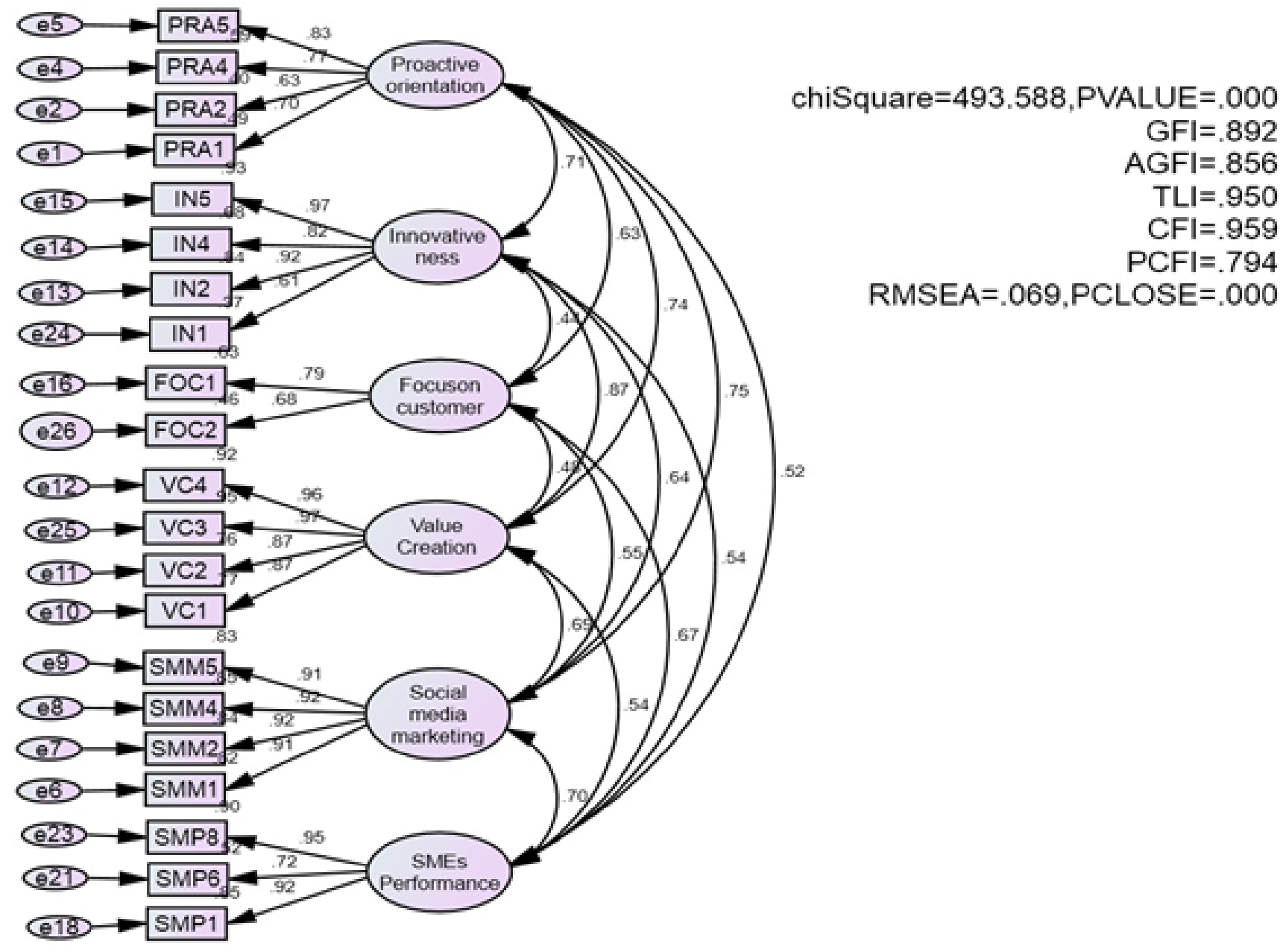

Fig 2. Confirmatory factor analysis: Modified model 
In Figure 3, the first tested path is A. The loadings for the path A is as; for proactive orientation dimension with four items have an average loading is .82, for Innovativeness dimension with four items have an average loading is .90, for focus on customer dimension with two items have an average loading is . 55 , for proactive active dimension with four items have an average loading is .94 and the social media marketing which is an endogenous construct with four items have an average loading of .92. All the tested dimensions and constructs have showed the high factor loadings while it shows that in the path. The EMS has 75\% impact on the SMEs performance which can be conformed from the AGFI of the model which is .886 . The model explains the relationship between the entrepreneurial marketing strategies and SMEs performance as very high level of $88 \%$. The data shows that the success of entrepreneurial marketing strategies 88 percent depends on SMM like marking on the different channels of SM.

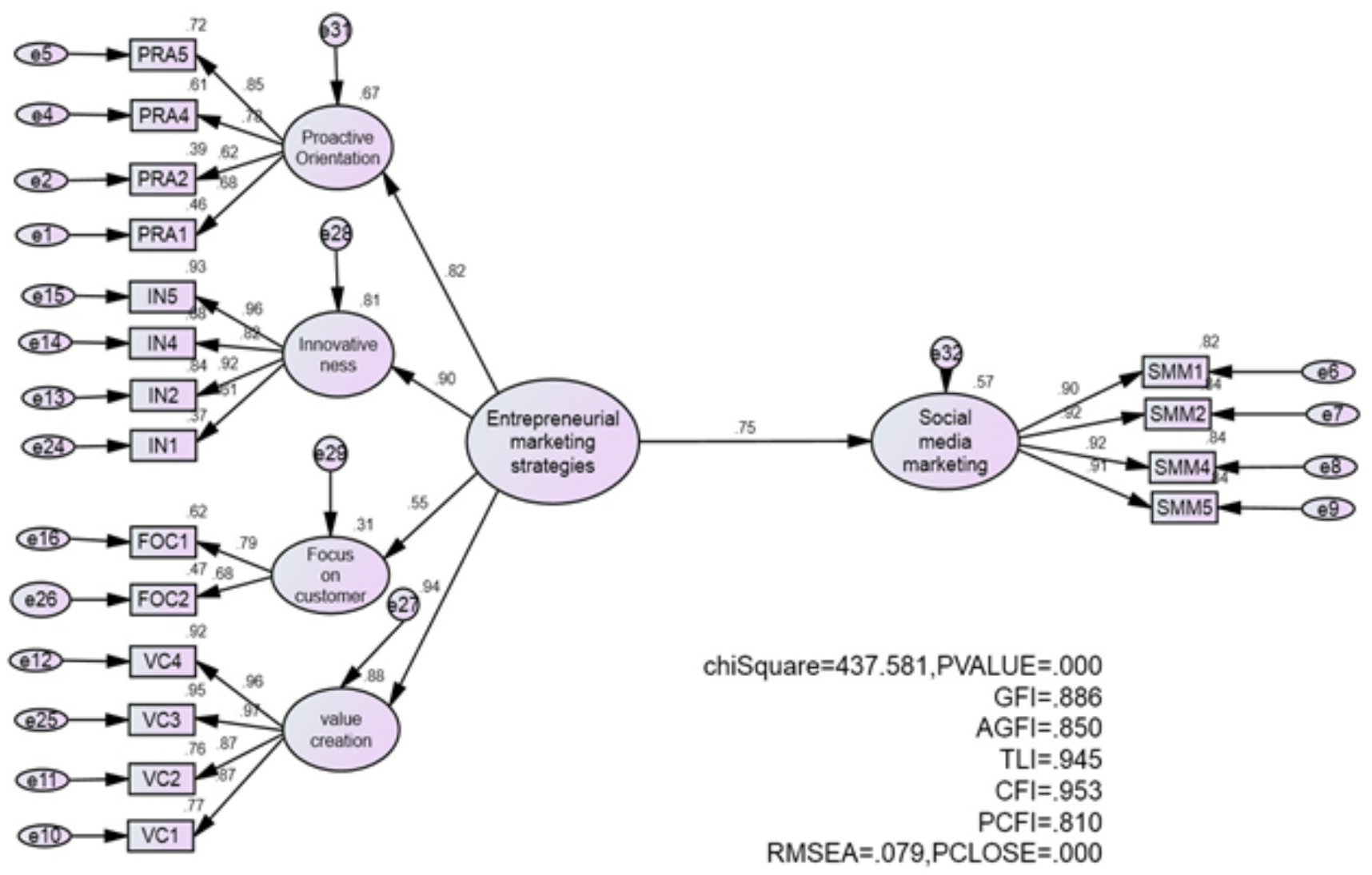

Fig 3. Path A: EMS to SMM

In Figure 4, path B is showed by an arrow starts from the social media marketing to SME performance. Loading average of 4 items of social media marketing is .91 which is quite well in the range of suggested parameters in the study of ${ }^{(47)}$. According to which if value of loadings very near to 1 , it is in the fitness range of fit indices. The loadings of 3 items of SME performance are similar as it of social media marketing. The beta ranges between the 1 and 0 to show the strong and weak relationship or impact $^{(47)}$. The beta shows the $69 \%$ impact or relation of social media marketing with SME performance. The GFI for diagram of Path B is .965 which shows fitness of model from the above values. 

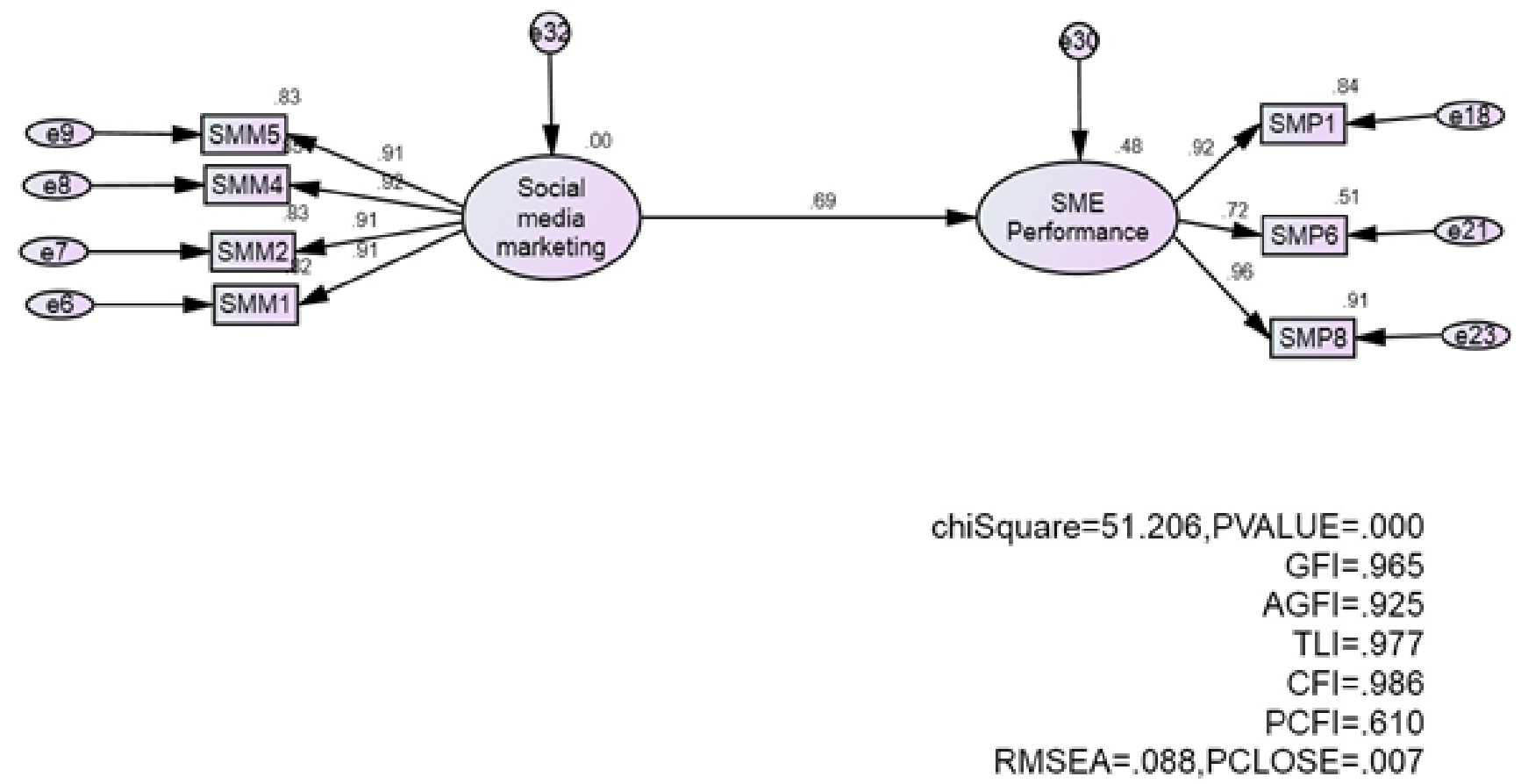

Fig 4. Path B: Relationship between social media marketing and SME performance

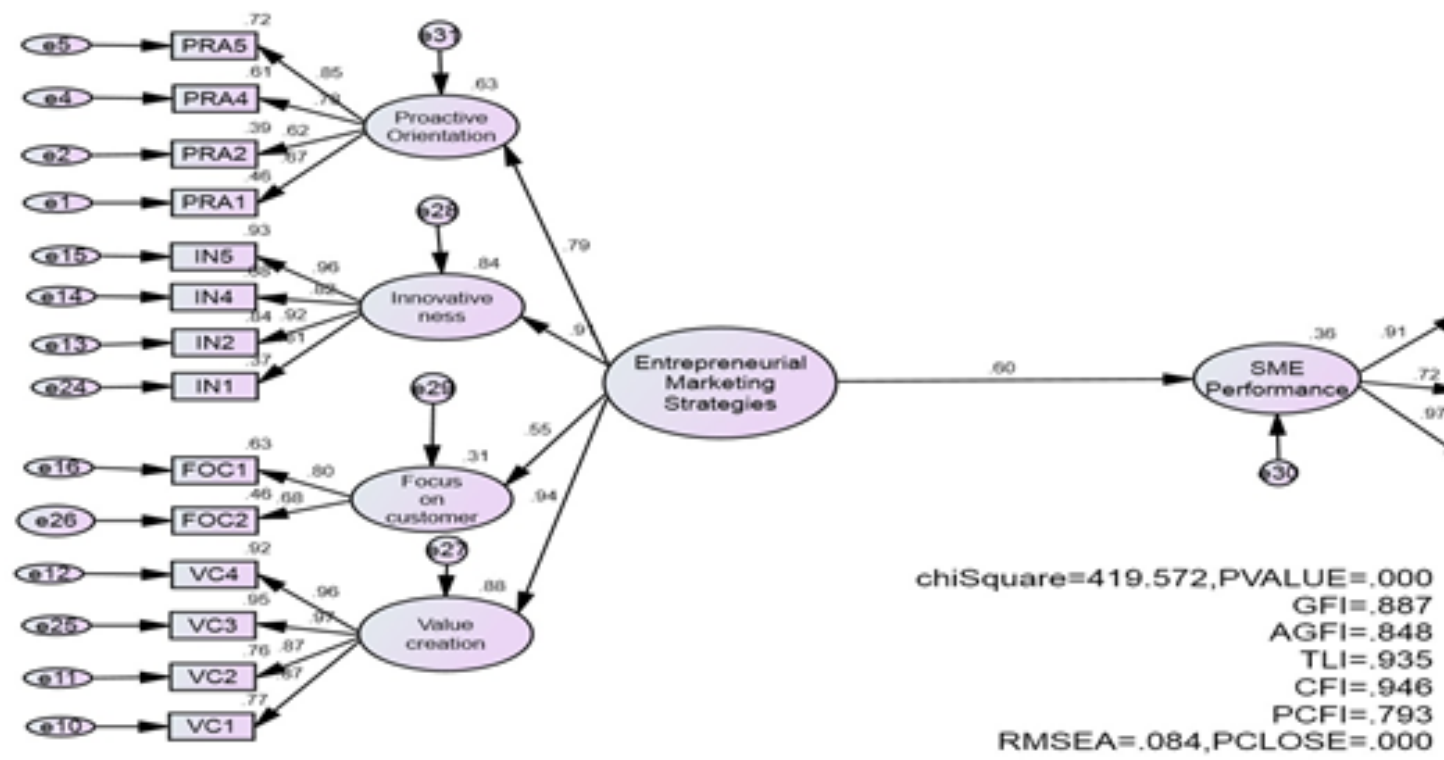

Fig 5. Path C: EMS to SME Performance

In Figure 5 , the path $\mathrm{C}$ is showed by an arrow starts from the entrepreneurial marketing strategies to SME performance. Loading average of 4 items of social media marketing is . 91 which is quite well in the range of suggested parameters in the study of ${ }^{(47)}$. According to which if the value of loadings very near to 1 , it is in the fitness range of fit indices. The loadings from of 3 items of SME performance are similar as if of EMS. The beta ranges between the 1 and 0 to show the strong and weak relation or impact ${ }^{(34)}$. The beta shows the $60 \%$ impact or relation of EMS with SME performance. The GFI for diagram of Path C is .887 which shows fitness of model from the above values. 
In Figure 6, the relationship between the entrepreneurial marketing strategies and the SMM, which is path A is .76 and the relationship between the social media marketing and SMEs Performance is .56 which is path B. The total indirect effect is .136 and direct effect is .19 , means the indirect effect is $>$ direct effect. ${ }^{(47)}$. If the direct effect is less than the indirect one than it is mediation, if the mediation values are positive it will be a positive mediation and if values are negatives than it is negative mediation. If, while entering the new construct between the two constructs, one of them, if will be insignificant than there is full mediation, but if P-value does not change and insertion of new variable lessen the different effect than it will be a partial mediation. Hence the $\mathrm{H} 4$ proved as accepted because values show that there is a partial mediation by following the Barron and Kenny philosophy of mediation.

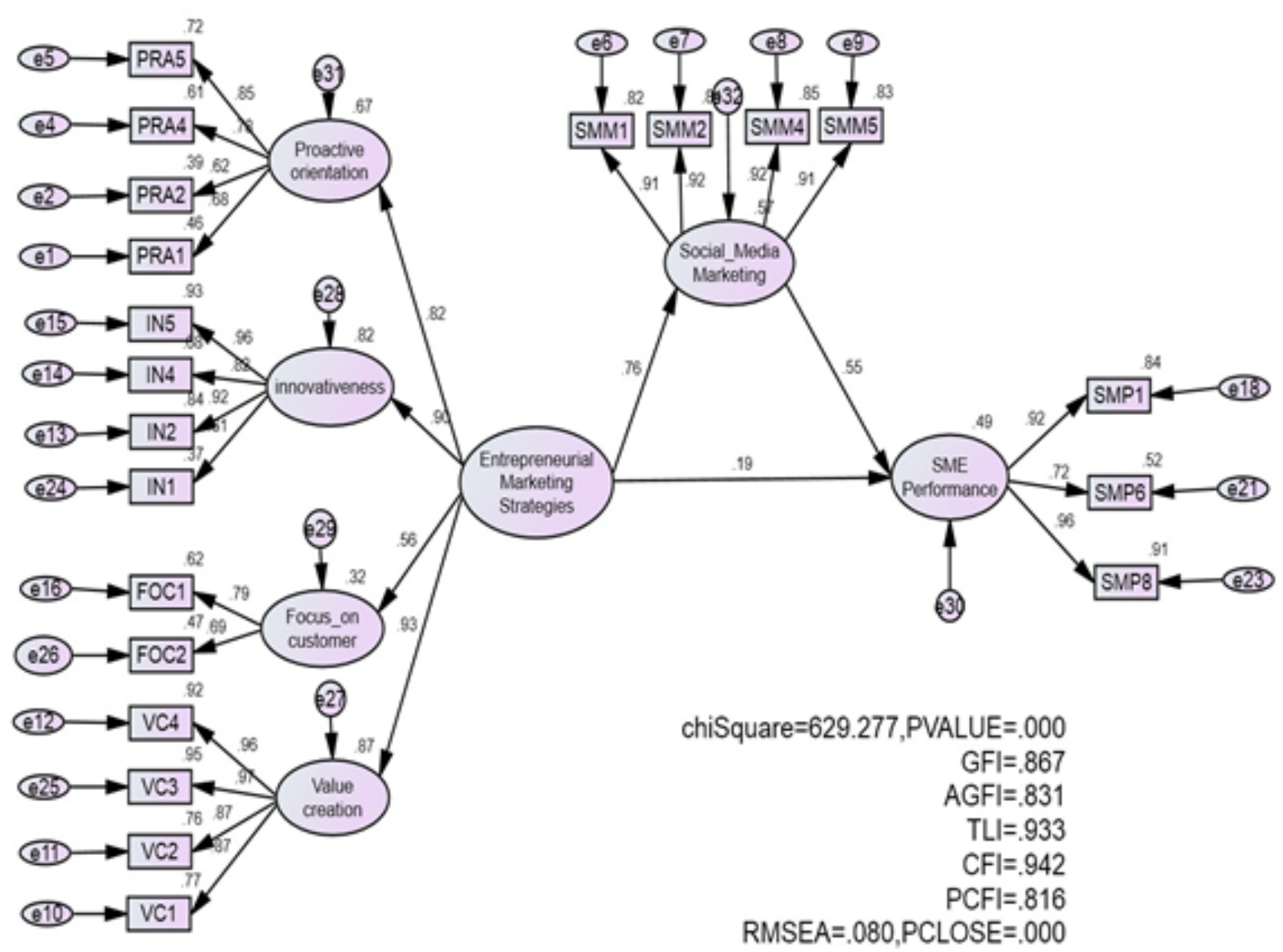

Fig 6. SEM: EMS, SMM, SME Performance

\section{Conclusion}

The research has tried to find the role of social media marketing between the relationship of entrepreneurial marketing strategies and Performance of SMEs. This research has answered the question that how social media marketing can be crucial for the entrepreneurial marketing to increase the performance of SMEs in Pakistan. The question or objective was to explore that either Social media marketing mediates the relationship between the entrepreneurial marketing strategies and performance of SMEs in the Pakistan or not? And it is found that Social media marketing according to mediation analysis results, partially mediates between the EMS and SMEs performance in Pakistan. Although there is a direct positive impact of EMS on SMEs performance but social media marketing like, Facebook marketing, twitter marketing, WhatsApp marketing, YouTube marketing further stimulates this impact on boarder level. The changing entrepreneurship scenario is now on the mercy of new technology like social media marketing. The four studied dimensions of entrepreneurship gives insight that proactive orientation can 
lead the business through the social media marketing, innovativeness can be achieved using new technology, social media marketing will help entrepreneurs to focus on customer's current needs and value for business can be created through the social media marketing. Entrepreneurs who do not use social media marketing cannot expand their business in the current technologically advanced markets. Marketing strategies if adopted can help entrepreneurs to achieve a comparative advantage on other entrepreneurs who have no knowledge of marketing strategies and use of social media marketing. Social media marketing is a greater source of advertising nowadays and it has replaced the old marketing patterns so entrepreneurs must not miss to take advantage of technology in shape of social media marketing like marketing through Facebook, twitter, LinkedIn, YouTube, WhatsApp and so many other channels of internet marketing so called social media marketing.

\section{References}

1) Jasra J, Hunjra AI, Rehman AU, Azam RI, Khan MA. Determinants of business success of small and medium enterprises. International Journal of Business and Social Science. 1920;2(20). Available from: https://doi.org/10.1109/icebeg.2011.5881712.

2) Ndubisi NO, Iftikhar K. Relationship between entrepreneurship, innovation and performance. Journal of Research in Marketing and entrepreneurship. 2012. Available from: https://doi.org/10.1108/14715201211271429.

3) Imran M, binti Aziz A, binti Abdul Hamid SN, Shabbir MS, Salman R, Jian Z. The mediating role of total quality management between entrepreneurial orientation and SMEs export performance. Management Science Letters. 2018;8(6):519-532. Available from: https://dx.doi.org/10.5267/j.msl.2018.5.003.

4) Hoque ASMM, Awang ZB. Does gender difference play moderating role in the relationship between entrepreneurial marketing and Bangladeshi SME performance? Accounting. 2019;5(1):35-52. Available from: https://dx.doi.org/10.5267/j.ac.2018.6.001.

5) Imran M, binti Abdul Hamid SN, binti Aziz A. The influence of TQM on export performance of SMEs: Empirical evidence from manufacturing sector in Pakistan using PLS-SEM. Management Science Letters. 2018;8(5):483-496. Available from: https://dx.doi.org/10.5267/j.msl.2018.3.003.

6) Hussain J, Ismail K, Akhtar CS. Market orientation and organizational performance: case of Pakistani SMEs. Arabian Journal of Business and Management Review. 2015;5(5):1-6. Available from: https://doi.org/10.1504/ijesb.2015.071825.

7) Athar T, Hashmi A, Ansari SG, Ansari ZA. Architectonics of Mesoporous Nanomaterials. Reviews in Advanced Sciences and Engineering. 2013;2:77-89. Available from: https://dx.doi.org/10.1166/rase.2013.1041.

8) Hassan MU, Iqbal Z, Malik M, Ahmad MI. Exploring the role of technological developments and open innovation in the survival of SMEs: an empirical study of Pakistan. International Journal of Business Forecasting and Marketing Intelligence. 2018;4(1):64-85. Available from: https://doi.org/10.1504/ijbfmi. 2018.088629.

9) Yousaf Z, Majid A. Organizational network and strategic business performance. Journal of Organizational Change Management. 2018. Available from: https://doi.org/10.1108/jocm-12-2016-0298.

10) Khaliq CA, Rehman CA, Roomi MA, Rehman S, Irem K. The role of social capital and knowledge management in the performance of SMEs: An empirical investigation in Pakistan. American Academic \& Scholarly Research Journal. 2014;6(4). Available from: https://doi.org/10.20944/preprints201905.0291.v1.

11) Soomro HJ, Khaskheli GA, Jumani AK, Shar AH. Intervening analysis of internet marketing between the relationship of brand awareness and online purchase decision of mobile products among the students of Heis in Pakistan. Indian Journal of Science and Technology. 2020;13(15):1535-1545. Available from: https://doi.org/10.17485/IJST/v13i15.39.

12) Khaskheli GA, H D. Intervening Effect of Social Media Advertising between the Relationship of Brand Awareness and Consumer's Online Buying Decisions among the Students of HEI's Of Sindh. International Journal of Future Generation Communication and Networking. 2020;p. 662-677. Available from: https://sersc.org/journals/index.php/IJFGCN/article/view/6569.

13) Imran MU, Aziz A, Hamid S. Moderating role of environmental turbulence on the relationship between entrepreneurial orientation, business networks orientation, export market orientation and SMEs export performance: a research framework. Journal of Business Management. 2016;4(15). Available from: https://doi.org/10.6007/ijarbss/v7-i10/3372.

14) Khalique M, Shaari JAN, Isa AHM, Ageel A. Role of Intellectual Capital on the Organizational Performance of Electrical and Electronic SMEs in Pakistan. International Journal of Business and Management. 2011;6(9). Available from: https://dx.doi.org/10.5539/ijbm.v6n9p253.

15) Hoque AS, Awang Z, Gwadabe UM. The Effect of Entrepreneurial Marketing on Bangladeshi SME performance and the Role of Organizational Culture: A Structural Equation Modelling. Journal of Management and Operation Research. 2018;1:1-21. Available from: https://doi.org/10.5267/j.ijdns.2018.7.001.

16) Qureshi MS, Aziz N, Mian SA. How marketing capabilities shape entrepreneurial firm’s performance? Evidence from new technology based firms in turkey. Journal of Global Entrepreneurship Research. 2017;7(1):15-15. Available from: https://dx.doi.org/10.1186/s40497-017-0071-5.

17) Terziovski M. Innovation practice and its performance implications in small and medium enterprises (SMEs) in the manufacturing sector: a resourcebased view. Strategic Management Journal. 2010;31(8):n/a-n/a. Available from: https://dx.doi.org/10.1002/smj.841.

18) Asad M, Sharif MN, Hafeez M. Moderating effect of network ties on the relationship between entrepreneurial orientation, market orientation, and performance of MSEs. Paradigms: A Research Journal of Commerce. 2016;10(2):69-76. Available from: https://doi.org/10.5539/ijbm.v6n9p253.

19) Khalique M, Bontis N, bin Shaari JAN, Isa AHM. Intellectual capital in small and medium enterprises in Pakistan. Journal of Intellectual Capital. 2015;16(1):224-238. Available from: https://dx.doi.org/10.1108/jic-01-2014-0014.

20) Hafeez MH, Shariff MN. bin Mad Lazim H. Does innovation and relational learning influence SME Performance? An Empirical Evidence from Pakistan. Asian Social Science. 2013;9(15):204-204. Available from: https://doi.org/10.5539/ass.v9n15p204.

21) Muhammad N, McElwee G, Dana LP. Barriers to the development and progress of entrepreneurship in rural Pakistan. International Journal of Entrepreneurial Behavior \& Research. 2017;23(2):279-295. Available from: https://dx.doi.org/10.1108/ijebr-08-2016-0246.

22) Sadiku-Dushi N, Dana LP, Ramadani V. Entrepreneurial marketing dimensions and SMEs performance. Journal of Business Research. 2019;100:86-99. Available from: https://dx.doi.org/10.1016/j.jbusres.2019.03.025.

23) Ramadani V, Demiri A, Demiri SS. Social media channels: the factors that influence the behavioural intention of customers. International Journal of Business and Globalisation. 2014;12(3):297-297. Available from: https://dx.doi.org/10.1504/ijbg.2014.060214.

24) Etemad H, Wilkinson I, Dana LP. Internetization as the necessary condition for internationalization in the newly emerging economy. Journal of International Entrepreneurship. 2010;8(4):319-342. Available from: https://dx.doi.org/10.1007/s10843-010-0062-x.

25) Robert F, Shoubaki AE, Lasch F, Dana LP. Linking types of ICT entrepreneurs to new firm survival. International Journal of Entrepreneurship and Small Business. 2017;30(1):110-156. 
26) Palalic R, Ramadani V, Gilani SM, Gërguri-Rashiti S, Dana L. Social media and consumer buying behavior decision: what entrepreneurs should know? Management Decision. 2020;ahead-of-print(ahead-of-print). Available from: https://dx.doi.org/10.1108/md-10-2019-1461.

27) Dana LP, Dana TE. Expanding the scope of methodologies used in entrepreneurship research. International Journal of Entrepreneurship and Small Business. 2005;2(1):79-79. Available from: https://dx.doi.org/10.1504/ijesb.2005.006071.

28) Husnain M, Khan MK, Syed F, Akhtar W. Exploring the Role of Founder Entrepreneur in Entrepreneurial Marketing Case Studies from SMEs in Pakistan. City Univeristy Research Journal;9:1-11. Available from: http://www.cityuniversity.edu.pk/curj/files/aic-18/01.pdf.

29) Ahmad I, Ahmad S. Multiple Skills and Medium Enterprises' Performance in Punjab Pakistan: A Pilot Study. The Journal of Social Sciences Research, Special. 2018;(4):44-53. Available from: https://doi.org/10.32861/jssr.spi4.44.49.

30) Omer MM. Marketing communication through social media: a exploratory case study of SMEs in Pakistan. Arabian Journal of Business and Management Review. 2015;5(5):1-3. Available from: https://doi.org/10.1016/j.indmarman.2015.12.004.

31) Fillis I. An Andalusian dog or a rising star? Creativity and the marketing/entrepreneurship interface. Journal of Marketing Management. 2002;18(3-4):37995. Available from: https://doi.org/10.1362/0267257022872415.

32) Rehman S, Roomi MA. Gender and work-life balance: a phenomenological study of women entrepreneurs in Pakistan. Journal of small business and enterprise development. 2012. Available from: https://doi.org/10.1108/14626001211223865.

33) Imran M, binti Aziz A, binti Abdul Hamid SN. The Relationship between Entrepreneurial Orientation, Business Networks Orientation, Export Market Orientation and SME Export Performance: A Proposed Research Framework. International Journal of Academic Research in Business and Social Sciences. 2017;7(10):230-278. Available from: https://dx.doi.org/10.6007/ijarbss/v7-i10/3372.

34) Tipu SA, Fantazy KA. Supply chain strategy, flexibility, and performance. The International Journal of Logistics Management. 2014. Available from: https://doi.org/10.1108/ijlm-01-2013-0001.

35) Haider SH, Asad M, Fatima M. Entrepreneurial orientation and business performance of manufacturing sector small and medium scale enterprises of Punjab Pakistan. . European Business and Management. 2017;3(2):21-29. Available from: https://doi.org/10.11648/j.ebm.20170302.12.

36) Islam MA, Khan MA, Obaidullah AZM, Alam MS. Effect of Entrepreneur and Firm Characteristics on the Business Success of Small and Medium Enterprises (SMEs) in Bangladesh. International Journal of Business and Management. 2011;6(3):289-289. Available from: https://dx.doi.org/10.5539/ ijbm.v6n3p289.

37) Khan MW, Khalique M. Entrepreneurial approach and intellectual capital in Pakistani manufacturing pharmaceutical organizations. In: 6th International Borneo Business Conference. 2014;p. 20-21. Available from: https://doi.org/10.1037/e550852013-030.

38) Hamali S, Suryana Y, Effendi N, Azis Y. Influence of entrepreneurial marketing toward innovation and its impact on business performance: A survey on small Industries of Wearing Apparel in West Java. Indonesia International Journal of Economics, Commerce and Management. 2016;4(8). Available from: https://doi.org/10.2991/icebef- 18.2019 .54$.

39) Laghari AA, He H, Karim S, Shah HA, Karn NK. Quality of experience assessment of video quality in social clouds. 2017. Available from: https: //doi.org/10.1155/2017/8313942.

40) Laghari AA, He H, Shafiq M, Khan A. Assessment of quality of experience (QoE) of image compression in social cloud computing. Multiagent and Grid Systems. 2018;14:125-143. Available from: https://dx.doi.org/10.3233/mgs-180284.

41) Laghari AA, He H, Khan A, Karim S. Impact of Video File Format on Quality of Experience (QoE) of Multimedia Content. 3D Research. 2018;9:39-39. Available from: https://dx.doi.org/10.1007/s13319-018-0191-x.

42) Karim S, He H, Mallah GA, Laghari AA, Madiha H, Larik RS. The Impact of Using Facebook on the Academic Performance of University Students. In: International Conference on Artificial Intelligence and Security. Springer. 2019;p. 405-418.

43) Laghari AA, Memon KA, Soomro MB, Laghari RA, Kumar V. Quality of experience (QoE) assessment of games on workstations and mobile. Entertainment Computing. 2020.

44) Madiha H, Lei L, Laghari AA, Karim S. Quality of Experience and Quality of Service of Gaming Services in Fog Computing. Proceedings of the 2020 4th International Conference on Management Engineering. 2020;p. 225-228.

45) Khan F, Saqib PS, Laghari AA, Memon KA. Social Networks Mining and Analysis of Specific Groups (Political and Regional) by using API. .

46) Jumani AK, Mahar J, Surahio F, Mahar M, Mahesar H, Talpur S. Destroy messages: design and development of software tool for WhatsApp. Sindh University Research Journal-SURJ. 2016;48(2).

47) Jumani AK, Memon MA, Kartio MA. A Technique to Measure Students' Mental Approach using Web and Game Based E-Learning Application. Annals of Emerging Technologies in Computing. 2018;2(3):19-26. Available from: https://dx.doi.org/10.33166/aetic.2018.03.003. 